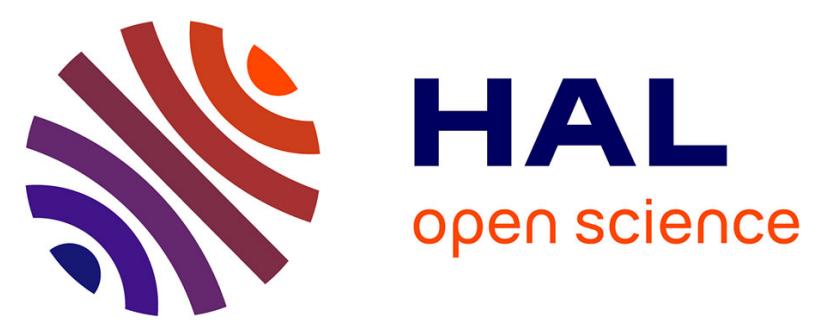

\title{
Synthesis, Characterization and Electrochemical Behavior of CoII, NiII and CdII Complexes with N2O2 \\ Donor Ligands Derived from 4,4'-Diaminobiphenyl and 2-Hydroxybenzaldehyde or 2,4-Dihydroxybenzaldehyde
}

Lakhdar Sibous, Embarek Bentouhami, Amor Maïza, Gilles Bouet, Mustayeen Ahmed Khan

\section{- To cite this version:}

Lakhdar Sibous, Embarek Bentouhami, Amor Maïza, Gilles Bouet, Mustayeen Ahmed Khan. Synthesis, Characterization and Electrochemical Behavior of CoII, NiII and CdII Complexes with N2O2 Donor Ligands Derived from 4,4'-Diaminobiphenyl and 2-Hydroxybenzaldehyde or 2,4Dihydroxybenzaldehyde. Journal of Solution Chemistry, 2010, 39 (4), pp.511-521. 10.1007/s10953010-9512-2 . hal-03250903

\section{HAL Id: hal-03250903 \\ https://univ-angers.hal.science/hal-03250903}

Submitted on 8 Jun 2021

HAL is a multi-disciplinary open access archive for the deposit and dissemination of scientific research documents, whether they are published or not. The documents may come from teaching and research institutions in France or abroad, or from public or private research centers.
L'archive ouverte pluridisciplinaire HAL, est destinée au dépôt et à la diffusion de documents scientifiques de niveau recherche, publiés ou non, émanant des établissements d'enseignement et de recherche français ou étrangers, des laboratoires publics ou privés. 


\title{
Synthesis, Characterization and Electrochemical Behavior of $\mathrm{Co}^{\mathrm{II}}, \mathrm{Ni}^{\mathrm{II}}$ and $\mathrm{Cd}^{\mathrm{II}}$ Complexes with $\mathrm{N}_{2} \mathrm{O}_{2}$ Donor Ligands Derived from 4,4'-Diaminobiphenyl and 2-Hydroxybenzaldehyde or 2,4-Dihydroxybenzaldehyde
}

\author{
Lakhdar Sibous • Embarek Bentouhami • Amor Maïza • \\ Gilles M. Bouet • Mustayeen Ahmed Khan
}

Received: 9 July 2009 / Accepted: 28 October 2009 / Published online: 26 March 2010

(C) Springer Science+Business Media, LLC 2010

\begin{abstract}
The condensation of 2-hydroxybenzaldehyde or 2,4-dihydroxybenzaldehyde with 4,4'-diaminobiphenyl in absolute EtOH in a molar ratio 2:1 gave, respectively, the Schiff base ligands $\mathrm{H}_{2} \mathrm{~L} 1$ or $\mathrm{H}_{2} \mathrm{~L} 2$. The bases served as tetradentate ligands to coordinate $\mathrm{Co}^{\mathrm{II}}$, $\mathrm{Ni}^{\mathrm{II}}$ and $\mathrm{Cd}^{\mathrm{II}}$ chlorides, leading to complexes where the metal:ligand ratio is $2: 1$. All of the compounds were characterized by elemental analysis, infrared, electronic and mass spectroscopy, ${ }^{1} \mathrm{H}$-n.m.r. and d.s.c. The cyclic voltammograms of the ligands and their complexes in DMF are discussed.
\end{abstract}

Keywords Schiff bases $\cdot$ Cobalt(II) complexes $\cdot$ Nickel(II) complexes $\cdot$ Cadmium(II) complexes $\cdot$ Cyclic voltammetry

\section{Introduction}

Since the first report of their metal complexes, Schiff base compounds have become an important class of ligands that have been extensively studied in coordination chemistry, mainly due to their facile synthesis and easily tunable steric, electronic and catalytic properties [1]. They are also used in constructing supramolecular structures [2-4].

Various transition metal complexes with bi- and tridentate Schiff bases containing nitrogen and oxygen donor atoms play an important role in biological systems and represent interesting models for metallo-enzymes, which efficiently catalyze the reduction of dinitrogen and dioxygen [5,6]. Furthermore, macrocyclic derivatives of these Schiff bases were

L. Sibous · E. Bentouhami · A. Maïza

Département de Génie des Procédés, Faculté des Sciences de l'Ingénieur, Université Ferhat Abbas,

Sétif 19000, Algeria

G.M. Bouet · M.A. Khan $(\bowtie)$

Chimie de Coordination, Faculté de Pharmacie, Université d'Angers, 16 Boulevard Daviers,

49045 Angers Cedex 01, France

e-mail: mustayeen.khan@univ-angers.fr 
found to have many fundamental biological functions such as photosynthesis and transport of oxygen in mammalian and other respiratory systems [7-9].

On the other hand, there is a great amount of research interest in the chemistry of the metal complexes of tetradentate $\mathrm{N}_{2} \mathrm{O}_{2}$ Schiff bases due to their ability to form adducts with dioxygen and thus may catalyze reduction of dioxygen. The transition metal ions in the complexes form adducts with dioxygen via charge transfer. These complexes will thus be expected to show catalytic effects. For instance, complexes of chromium and ruthenium with a wide variety of Schiff bases having donor atoms such as $\mathrm{N}_{2} \mathrm{O}_{2}$ and $\mathrm{N}_{4}$ around the metal ion have been used as catalysts for carbonylation, hydrogenation, hydroformylation and epoxydation reactions [10-12]. The cobalt and manganese complexes that coordinate through $\mathrm{N}_{2} \mathrm{O}_{2}$ donor atoms have been extensively studied as oxygen carriers and also as catalysts for water splitting systems [13, 14].

Macrocyclic ligands also have coordination properties and have attracted much attention [15-17]. Cadmium is an environmental pollutant that inhibits ribonucleic acid (RNA) polymerase activity in vivo $[18,19]$ and reacts readily with proteins and other biological molecules. Consequently, the macrocyclic chemistry of cadmium has recently been developed [20].

Thus, in view of the above preceding research, it was considered worthwhile to prepare some new metal-based macrocyclic skeletons bearing multiple donor sites that could probably be used for the binding of some guest molecules. The present work deals with the synthesis, characterization and cyclic voltammetry of two Schiff-base ligands derived from the condensation of 4,4'-diaminobiphenyl with 2-hydroxybenzaldehyde or 2,4dihydroxybenzaldehyde and their $\mathrm{Co}^{2+}, \mathrm{Ni}^{2+}$ and $\mathrm{Cd}^{2+}$ complexes.

\section{Experimental}

\subsection{Materials}

All materials and solvents were analytical reagent grade and were used without further purification. 2-Hydroxybenzaldehyde, 2,4-dihydroxybenzaldehyde and 4,4'-diaminobiphenyl were purchased from Aldrich. All metals were used in the form of their hydrated chlorides and were used as received.

\subsection{Measurements}

The ${ }^{1} \mathrm{H}$-n.m.r. spectra of the ligands and the diamagnetic complexes were recorded on a Jeol GSX WB spectrometer at $270 \mathrm{MHz}$ in $\mathrm{DMSO}_{-} \mathrm{D}_{6}$; the chemical shifts are given in p.p.m., using tetramethylsilane (TMS) as the internal reference. The IR spectra were recorded with a Perkin-Elmer 1000 series FT-IR spectrophotometer using KBr disks. The UV-vis spectra were obtained in DMF with a UNICAM UV-300 spectrophotometer. The electron impact mass spectra (ESI) were recorded on a Bruker Daltonics Data Analysis 3.1 spectrometer. The melting points were determined with a Kofler bench and are uncorrected. Differential scanning calorimetry (d.s.c.) diagrams were recorded in the $25-400{ }^{\circ} \mathrm{C}$ range with a Mettler DSC $822^{\mathrm{e}}$ unit, with the help of Mettler Toledo STAR ${ }^{\mathrm{e}}$ SW 8.10 System software. The heating rate was $10^{\circ} \mathrm{C}$ per minute, and all measurements were made in $40 \mathrm{~mm}^{3}$ closed aluminum crucibles.

The elemental analyses were carried out with an EL III-ELEMENTAR. All of these measurements were performed in France. Electrochemical measurements were recorded on 
a Radiometer VOLTALAB 32 (DEA 332 type): the working electrode was a $2 \mathrm{~mm}$ diameter $\mathrm{Pt}$ rotating disk and the auxiliary electrode was a Pt wire. A saturated calomel electrode (SCE) was used as the reference electrode and measurements were carried out at $27^{\circ} \mathrm{C}$. DMF was used as the solvent, and the ionic strength was maintained at $0.1 \mathrm{~mol} \cdot \mathrm{L}^{-1}$ with $\mathrm{Bu}_{4} \mathrm{NClO}_{4}$ (TBAP) as supporting electrolyte. The concentrations of individual chemical species were in the $2.5 \times 10^{-3}$ to $5 \times 10^{-3} \mathrm{~mol} \cdot \mathrm{L}^{-1}$ range. The sweep speed was $100 \mathrm{mV} \cdot \mathrm{s}^{-1}$ unless otherwise indicated.

\subsection{Preparation of the Ligands}

The ligands were prepared by condensation of 4,4'-diaminobiphenyl with 2-hydroxybenzaldehyde for $\mathrm{H}_{2} \mathrm{~L} 1$, and with 2,4-dihydroxybenzaldehyde for $\mathrm{H}_{2} \mathrm{~L} 2$. The reactions were carried out in EtOH (1:2 molar ratio) [21,22]. To a solution of 4,4'-diaminobiphenyl $\left(0.43 \mathrm{~mol} \cdot \mathrm{L}^{-1}\right)$ in absolute $\mathrm{EtOH}$ was added a solution of 2-hydroxybenzaldehyde or 2,4-dihydroxybenzaldehyde $\left(0.87 \mathrm{~mol} \cdot \mathrm{L}^{-1}\right)$. The mixture was stirred under a nitrogen atmosphere and refluxed for $3 \mathrm{~h}$. The ligand was recovered by filtration, washed twice with EtOH $(10 \mathrm{~mL})$ and dried under vacuum.

\subsection{Preparation of the Complexes}

All of the complexes were prepared using a synthetic pathway described in the literature [23-26], by mixing appropriate amounts of ligand $\mathrm{H}_{2} \mathrm{~L} 1$ or $\mathrm{H}_{2} \mathrm{~L} 2\left(0.1 \mathrm{~mol} \cdot \mathrm{L}^{-1}\right)$ and a hydrated metal chloride in 1:2 molar ratio in absolute EtOH. After standing under reflux conditions for $8 \mathrm{~h}$, the mixture was then kept overnight at room temperature. The complex that precipitated was removed by filtration, washed several times with $\mathrm{EtOH}$ and dried under vacuum. Their purity was verified using thin layer chromatography (t.l.c.) with $\mathrm{CH}_{2} \mathrm{Cl}_{2} / \mathrm{EtOH}$ $(7: 3 \mathrm{v} / \mathrm{v})$ as eluent.

\section{Results and Discussion}

\subsection{Synthesis and Characterization}

The Schiff base ligands $\mathrm{H}_{2} \mathrm{~L} 1$ and $\mathrm{H}_{2} \mathrm{~L} 2$ were synthesized according to Fig. 1 and serve as tetradentate ligands in all six complexes reported in this account. The ligands employ two<smiles>[R]c1ccc(/C=N\c2ccc(-c3ccc(/N=C(\C=[Ge][Ga])c4ccc([R])cc4O)cc3)cc2)c(O)c1</smiles>

Fig. 1 Synthesis pathway for the Schiff base ligands 
Table 1 Main analytical data for the ligands and their complexes

\begin{tabular}{lllllll}
\hline Compound & Color & Yield $(\%)$ & $\mathrm{M}^{+} / \mathrm{g} \cdot \mathrm{mol}^{-1}$ & \multicolumn{4}{l}{ Elemental analysis, found (Calcd.) $(\%)$} \\
\cline { 5 - 7 } & & & & $\mathrm{C}$ & $\mathrm{H}$ & $\mathrm{N}$ \\
\hline $\mathrm{H}_{2} \mathrm{~L} 1$ & Yellow & 73 & 392.0 & $79.36(79.51)$ & $5.30(5.10)$ & $6.76(7.13)$ \\
$\left(\mathrm{CoCl}_{2}\right)_{2} \mathrm{~L} 1$ & Yellow & 60 & 650.0 & $47.91(47.99)$ & $3.05(2.77)$ & $4.42(4.31)$ \\
{$\left[\left(\mathrm{NiCl}_{2}\right)_{2} \mathrm{~L} 1\right] \cdot 2 \mathrm{H}_{2} \mathrm{O}$} & Yellow & 57 & - & $45.11(45.52)$ & $3.32(3.20)$ & $4.23(4.08)$ \\
$\left(\mathrm{CdCl}_{2}\right)_{2} \mathrm{~L} 1$ & Orange & 45 & 757.0 & $41.50(41.22)$ & $2.55(2.37)$ & $3.85(3.69)$ \\
$\mathrm{H}_{2} \mathrm{~L}_{2}$ & Tan & 51 & 424.0 & $73.40(73.51)$ & $5.02(4.71)$ & $6.34(6.59)$ \\
$\left(\mathrm{CoCl}_{2}\right)_{2} \mathrm{~L} 2$ & Brown & 60 & - & $46.05(45.76)$ & $2.96(2.64)$ & $3.91(4.10)$ \\
$\left(\mathrm{NiCl}_{2}\right)_{2} \mathrm{~L} 2$ & Green & 46 & 681.6 & $46.01(45.78)$ & $2.81(2.64)$ & $4.25(4.10)$ \\
$\left(\mathrm{CdCl}_{2}\right)_{2} \mathrm{~L} 2$ & Brown & 50 & - & $39.37(39.55)$ & $2.50(2.28)$ & $3.84(3.55)$ \\
\hline
\end{tabular}

imine nitrogens and two phenoxo oxygens to bind the metals. All complexes were synthesized in good yield by the reaction of the hydrated metal chlorides of $\mathrm{Co}^{\mathrm{II}}, \mathrm{Ni}^{\mathrm{II}}$ and $\mathrm{Cd}^{\mathrm{II}}$ with $\mathrm{H}_{2} \mathrm{~L} 1$ or $\mathrm{H}_{2} \mathrm{~L} 2$ in a molar ratio of $2: 1$, using ethanol as solvent at $50{ }^{\circ} \mathrm{C}$. Analytically pure compounds were obtained in all cases as indicated by elemental analysis, with melting points higher than $260^{\circ} \mathrm{C}$, and are consistent with the proposed molecular formulae that show the ratio of metal to ligand to be $2: 1$ in all cases. The main analytical data for the ligands and their complexes are given in Table 1.

\subsection{Mass Spectrometry}

The molecular weights of all prepared compounds were determined from their spectra using electron impact (EI) conditions. Parent ion peaks $\mathrm{M}^{+}$corresponding to the ligands and some of the complexes were present. The spectra also showed peaks attributed to $\left(\mathrm{M}^{+}+1 \mathrm{H}\right)$ and $\left(\mathrm{M}^{+}+2 \mathrm{H}\right)$, together with prominent breakdown peaks that corresponded to a loss of chlorine atoms in the cases of the nickel(II) and cobalt(II) complexes. These results agree with the expected structures and are mentioned in Table 1.

\subsection{Infrared Spectra}

In the IR spectra of the ligands, the broad bands in the $3232-3625 \mathrm{~cm}^{-1}$ range are attributed to the $v(\mathrm{O}-\mathrm{H})$ stretching vibration of the phenolic groups [27]. In the case of the nickel(II) complex with ligand $\mathrm{H}_{2} \mathrm{~L} 1$, this broad band results from the presence of water molecules according to the d.s.c. results. The bands in the 1282, 1284, 1620, and $1631 \mathrm{~cm}^{-1}$ regions are assigned to the stretching vibrations $v(\mathrm{C}-\mathrm{O})$ and $v(\mathrm{C}=\mathrm{N})$ of $\mathrm{H}_{2} \mathrm{~L} 1$ and $\mathrm{H}_{2} \mathrm{~L} 2$, respectively (Table 2). The $v(\mathrm{C}=\mathrm{N})$ band of the ligands undergoes small shifts to lower frequencies in the spectra of the complexes $\left(1600-1572 \mathrm{~cm}^{-1}\right)$, indicating coordination of the imine nitrogen [28-31]. Additional evidence for coordination of the nitrogen is the presence of a $v(M-N)$ band in the $437-497 \mathrm{~cm}^{-1}$ region.

Coordination through the oxygen atom is inferred from the shifts to lower wavenumbers of the $v(\mathrm{C}-\mathrm{O})$ band as compared to their position in the ligands [32], and the appearance of a new band in the $528-586 \mathrm{~cm}^{-1}$ region assigned to $v(\mathrm{M}-\mathrm{O})$, in agreement with earlier reported results [33-36]. 
Table 2 Main spectroscopic data for the ligands and their complexes

\begin{tabular}{|c|c|c|c|c|c|c|c|}
\hline \multirow[t]{2}{*}{ Compound } & \multicolumn{5}{|c|}{ Infrared $\left(\mathrm{cm}^{-1}\right)$} & \multirow{2}{*}{$\begin{array}{l}\text { UV-vis } \\
\lambda_{\max }(\mathrm{nm})\end{array}$} & \multirow{2}{*}{$\begin{array}{l}\text { (DMF solution) } \\
{\left[\varepsilon / \mathrm{L} \cdot \mathrm{mol}^{-1} \cdot \mathrm{cm}^{-1}\right]}\end{array}$} \\
\hline & $\overline{v(\mathrm{O}-\mathrm{H})}$ & $v(\mathrm{C}=\mathrm{N})$ & $v(\mathrm{C}-\mathrm{O})$ & $v(\mathrm{M}-\mathrm{O})$ & $v(\mathrm{M}-\mathrm{N})$ & & \\
\hline $\mathrm{H}_{2} \mathrm{~L} 1$ & 3454 & 1620 & 1282 & - & - & 366 & [13600] \\
\hline$\left(\mathrm{CoCl}_{2}\right)_{2} \mathrm{~L} 1$ & - & 1572 & 1250 & 572 & 437 & 370 & {$[20361]$} \\
\hline$\left[\left(\mathrm{NiCl}_{2}\right)_{2} \mathrm{~L} 1\right] \cdot 2 \mathrm{H}_{2} \mathrm{O}$ & 3360 & 1599 & 1220 & 528 & 493 & 370 & {$[5388]$} \\
\hline$\left(\mathrm{CdCl}_{2}\right)_{2} \mathrm{~L} 1$ & - & 1600 & 1238 & 574 & 438 & 368 & {$[18373]$} \\
\hline $\mathrm{H}_{2} \mathrm{~L} 2$ & 3363 & 1631 & 1284 & - & - & 368 & [19204] \\
\hline$\left(\mathrm{CoCl}_{2}\right)_{2} \mathrm{~L} 2$ & 3625 & 1595 & 1242 & 586 & 497 & 380 & [21936] \\
\hline$\left(\mathrm{NiCl}_{2}\right)_{2} \mathrm{~L} 2$ & 3288 & 1595 & 1271 & 563 & 489 & 376 & {$[25744]$} \\
\hline$\left(\mathrm{CdCl}_{2}\right)_{2} \mathrm{~L} 2$ & 3232 & 1596 & 1247 & 584 & 491 & 378 & [27412] \\
\hline
\end{tabular}

\subsection{Electronic Spectra}

The band maxima $\left(\lambda_{\max }\right)$ and molar absorptivities $(\varepsilon)$ obtained from the electronic spectra of the ligands and complexes were recorded in DMF and the relevant data are presented in Table 2. In general, the UV-visible region of the electronic spectra of these compounds was dominated by intense intra-ligand $\pi-\pi^{*}$ transitions.

All of the complexes exhibit an absorption band in the $370-380 \mathrm{~nm}$ range, which is assigned to a metal-ligand charge transfer band.

In the case of the cobalt(II) complex of ligand $\mathrm{H}_{2} \mathrm{~L} 2$, two weak bands from $\mathrm{d}-\mathrm{d}$ transitions, not mentioned in Table 2, were observed at 606 and $654 \mathrm{~nm}$ and correspond to a tetrahedral environment around the $\mathrm{Co}^{2+}$ ion $[37,38]$.

\section{$3.5{ }^{1}$ H-n.m.r. Spectra}

The observations obtained from the previous analysis were further substantiated by the comparison of ${ }^{1} \mathrm{H}$-n.m.r. spectra of the free symmetrical ligands $\mathrm{H}_{2} \mathrm{~L} 1$ and $\mathrm{H}_{2} \mathrm{~L} 2$ and their complexes, which were recorded in DMSO- $\mathrm{D}_{6}$ solutions.

The aromatic protons of the ligands showed multiplets at $\delta=7.7-6.92$ and 7.97.2 p.p.m., assigned to both phenyl and bipyridyl protons of $\mathrm{H}_{2} \mathrm{~L} 1$ and $\mathrm{H}_{2} \mathrm{~L} 2$, respectively. These protons, in each case, could not be distinguished from each other. The spectra also contained absorptions at $\delta=9.3$ and 8.9 p.p.m. that are ascribed to the protons of the azomethine groups, while the singlets at $\delta=13.1$ and 13.6 p.p.m. are typical of hydroxyl protons. The remaining $-\mathrm{OH}$ absorption of $\mathrm{H}_{2} \mathrm{~L} 2$ occurred at $\delta=10.95$ p.p.m. These chemical shifts may be compared with those of literature $[39,40]$ where the hydroxyl proton of 2hydroxybenzaldehyde or 2-hydroxyacetophenone is reported to resonate at $\delta=12.05$ p.p.m. This deshielding, in fact, is due to the formation of intramolecular hydrogen bonding. For $\mathrm{H}_{2} \mathrm{~L} 1$ and $\mathrm{H}_{2} \mathrm{~L} 2$ the interaction is exclusively with the nitrogen atoms of the azomethine groups.

This difference becomes more important in the corresponding nickel(II) complexes NiL1 and NiL2, for example, where the aromatic protons in each case gave rise to a multiplet at $\delta=8-7.25$ p.p.m., while the protons of the azomethine groups become deshielded and appeared at $\delta=10.2$ and 9.1 p.p.m., respectively, for the same reasons as those previously indicated for the hydroxyl protons. This fact is supported by a higher structural rigidity leading to the coplanarity of the different $\mathrm{sp}^{2}$ systems constituting the complex, according to the square planar geometry generally observed for nickel complexes [41]. 
Table 3 Voltammetric results (anodic $E_{\mathrm{pa}}$, cathodic $E_{\mathrm{pc}}$ ) at room temperature in $\mathrm{DMF}$ at the ionic strength $0.1 \mathrm{~mol} \cdot \mathrm{L}^{-1}$ (TBAP) reported in $\mathrm{V}$ versus $\mathrm{SCE}$; sweep speed $100 \mathrm{mV} \cdot \mathrm{s}^{-1}$

\begin{tabular}{lcccccccc}
\hline Compound & $E_{\mathrm{pa} 1}$ & $E_{\mathrm{pa} 2}$ & $E_{\mathrm{pa} 3}$ & $E_{\mathrm{pc} 1}$ & $E_{\mathrm{pc} 2}$ & $E_{\mathrm{pc} 3}$ & $\Delta E$ & $E_{1 / 2}$ \\
\hline $\mathrm{H}_{2} \mathrm{~L} 1$ & & 1.05 & 1.60 & & 0.32 & & -0.73 & 0.685 \\
$\left(\mathrm{CoCl}_{2}\right)_{2} \mathrm{~L} 1$ & 0.46 & & 0.96 & & & -1.46 & & \\
{$\left[\left(\mathrm{NiCl}_{2}\right)_{2} \mathrm{~L} 1\right] \cdot 2 \mathrm{H}_{2} \mathrm{O}$} & 0.47 & 0.68 & 1.24 & 1.10 & & -1.50 & -0.14 & 1.170 \\
$\left(\mathrm{CdCl}_{2}\right)_{2} \mathrm{~L} 1$ & 0.45 & & & & & -1.43 & & \\
$\mathrm{H}_{2} \mathrm{~L} 2$ & 0.56 & 1.03 & & & 0.31 & & -0.25 & 0.435 \\
$\left(\mathrm{CoCl}_{2}\right)_{2} \mathrm{~L} 2$ & 0.52 & 0.74 & 1.20 & 1.06 & & -1.50 & -0.14 & 1.130 \\
$\left(\mathrm{NiCl}_{2}\right)_{2} \mathrm{~L} 2$ & 0.66 & 0.81 & & 1.01 & & -1.68 & 0.20 & 0.910 \\
$\left(\mathrm{CdCl}_{2}\right)_{2} \mathrm{~L} 2$ & 0.52 & & & & & -1.50 & & \\
\hline
\end{tabular}

In addition to this, the disappearance of the hydroxyl protons at $\delta=13.1$ and 13.6 p.p.m. in the ${ }^{1} \mathrm{H}$-n.m.r. spectra of the complexes obviously indicates that the $-\mathrm{OH}$ groups becomes deprotonated during coordination. The absorption that is observed at $\delta=10.53$ p.p.m. in the NiL2 spectrum is due to the remaining hydroxyl group in position four of the azomethine group.

\subsection{Thermal Analysis}

The d.s.c. diagrams show significant differences among the ligands $\mathrm{H}_{2} \mathrm{~L} 1, \mathrm{H}_{2} \mathrm{~L} 2$ and their complexes. The decomposition of all these compounds occurs at temperatures higher than $300{ }^{\circ} \mathrm{C}$ and is generally followed by several exothermic peaks due to this decomposition.

The d.s.c. diagram of the nickel(II) complex derived from $\mathrm{H}_{2} \mathrm{~L} 1$ shows many peaks at the $130-200{ }^{\circ} \mathrm{C}$ range that are due to the loss of water molecules.

The cobalt(II) and cadmium(II) complexes of ligand $\mathrm{H}_{2} \mathrm{~L} 1$ or $\mathrm{H}_{2} \mathrm{~L} 2$ are very stable thermally and show endothermic peaks in the $360-390{ }^{\circ} \mathrm{C}$ range. These results are in good agreement with literature values [42].

\subsection{Electrochemical Behavior of the Ligands and the Complexes}

The main electrochemical results for the ligands and the complexes in this study are summarized in Table 3 and some representative voltammograms are shown in Fig. 2.

\subsection{Ligands}

In the -1.8 to +1.8 range, the cyclic voltammogram of the ligand $\mathrm{H}_{2} \mathrm{~L} 1$ (Fig. 2a) shows two waves on the anodic side, with peak potentials of +1.05 and $+1.60 \mathrm{~V}$ that can be ascribed to the irreversible oxidations of the phenol moieties, and one cathodic peak at $+0.32 \mathrm{~V}$ due to the reduction of the oxidized species of the ligand (oxidation of the azomethine moiety) [43].

In the case of $\mathrm{H}_{2} \mathrm{~L} 2$ (Fig. 2b), the cyclic voltammogram shows two irreversible waves on the anodic side with only one cathodic peak. The potentials of the anodic peaks are at +0.56 and $+1.03 \mathrm{~V}$. During the reduction sweep, a broad cathodic peak was obtained at $+0.31 \mathrm{~V}$ resulting from reduction of the imino group. This ligand seems to have an increased tendency towards oxidation due to the presence of the electron donating groups $(\mathrm{OH})$ in the meta-positions of the phenol moieties, leading to lower oxidation potentials. Electron withdrawing substituents usually yield shifts to more positive potentials [44]. 

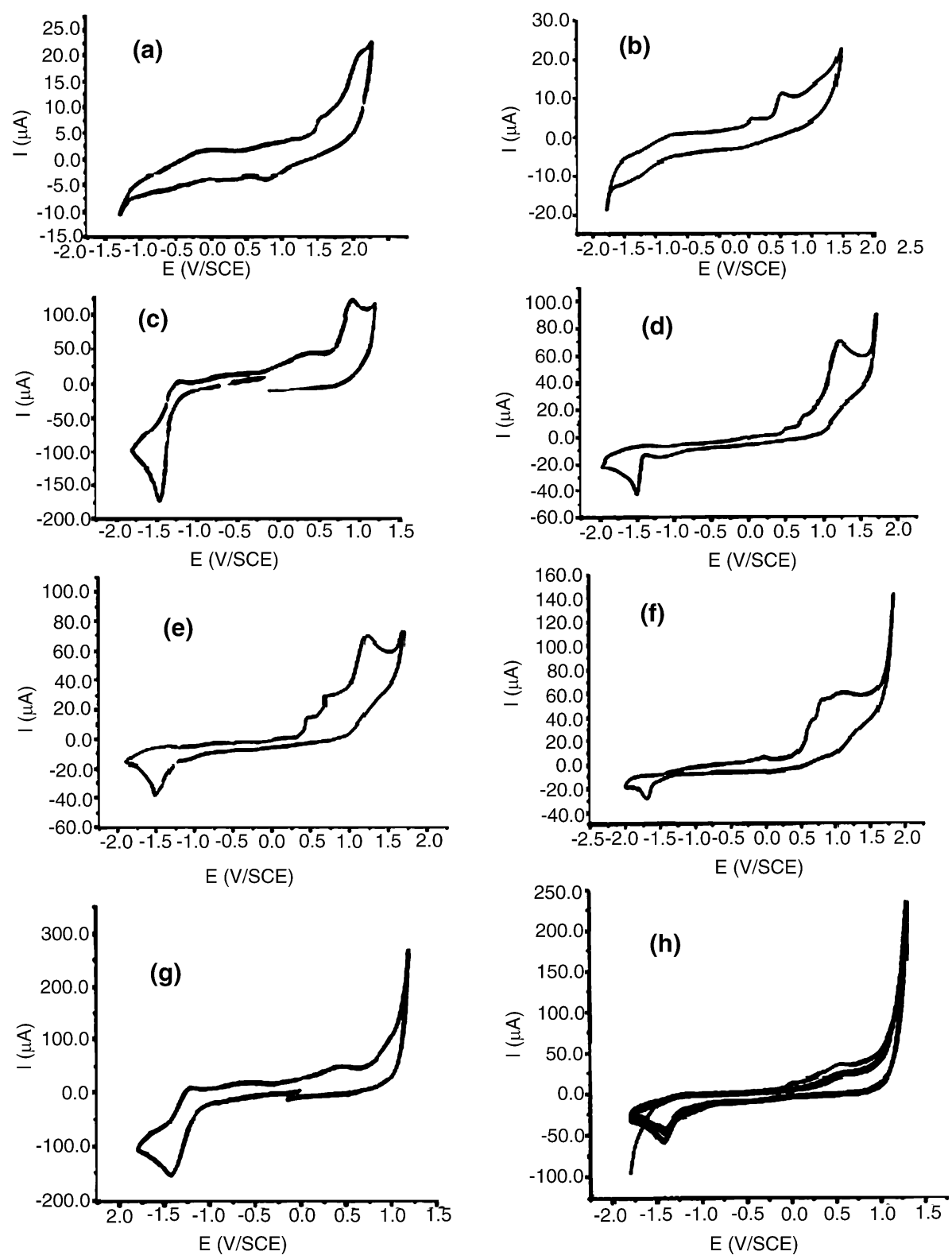

Fig. 2 Representative cyclic voltammograms in DMF $\left(25^{\circ} \mathrm{C}\right.$, ionic strength of $0.1 \mathrm{~mol} \cdot \mathrm{L}^{-1}, \mathrm{Bu}_{4} \mathrm{NClO}_{4}$, $i$ in $\mu \mathrm{A}, v=100 \mathrm{mV} \cdot \mathrm{s}^{-1}$ ) of: $\mathrm{H}_{2} \mathrm{~L} 1(\mathbf{a}), \mathrm{H}_{2} \mathrm{~L} 2(\mathbf{b}), \mathrm{Co}^{\mathrm{II}} \mathrm{L} 1(\mathbf{c}), \mathrm{Co}^{\mathrm{II}} \mathrm{L} 2(\mathbf{d}), \mathrm{Ni}^{\mathrm{II}} \mathrm{L} 1(\mathbf{e}), \mathrm{Ni}^{\mathrm{II}} \mathrm{L} 2(\mathbf{f}), \mathrm{Cd}^{\mathrm{II}} \mathrm{L} 1(\mathbf{g})$, and $\mathrm{Cd}^{\mathrm{II}} \mathrm{L} 2(\mathbf{h})$

\subsection{Complexes}

Because the ligands used in this electrochemical examination are not reversibly oxidized or reduced in the applied potential range, the behavior of the complexes showed similar responses that could be considered as the sum of the individual response of the metal center 
and of the ligands. For example, there are no $E_{\mathrm{pa} 1}$ and $E_{\mathrm{pc} 1}$ peaks for $\mathrm{H}_{2} \mathrm{~L} 1$, whereas for its nickel complex there is a new oxidation peak $E_{\mathrm{pa} 1}$ at $+0.47 \mathrm{~V}$ and a new reduction peak $E_{\mathrm{pc} 1}$ at $+1.10 \mathrm{~V}$. This clearly indicates that there is an effect from the metal center on the electrochemical properties. The voltammetric responses of the cobalt(II) complexes show cathodic peaks at $-1.46 \mathrm{~V}$ corresponding to the reduction of complexed $\mathrm{Co}^{\mathrm{II}}$ to $\mathrm{Co}^{0}$ for $\mathrm{H}_{2} \mathrm{~L} 1$ (Fig. 2c) and $-1.50 \mathrm{~V}$ and $+1.06 \mathrm{~V}$ for $\mathrm{H}_{2} \mathrm{~L} 2$ (Fig. 2d). The electrooxidation of $\mathrm{Co}^{0}$ to $\mathrm{Co}^{\mathrm{II}}$ in these species, in addition to those of the ligands (observed at nearly the same potential values as the corresponding $\mathrm{H}_{2} \mathrm{~L} 1$ and $\mathrm{H}_{2} \mathrm{~L} 2$ ), occur at +0.46 and $+0.52 \mathrm{~V}$. These values agree with those previously published for cobalt complexes in the same solvent [45].

In the case of nickel(II) complexes, the cyclic voltammograms on the negative scan show four reduction peaks at -1.50 and $+1.10 \mathrm{~V}$ for $\mathrm{Ni}$ (II)L1 (Fig. 2e), and -1.68 and $+1.01 \mathrm{~V}$ for $\mathrm{Ni}$ (II)L2 (Fig. 2f). The cathodic waves at $-1.50 \mathrm{~V}$ and $-1.68 \mathrm{~V}$ correspond to the reductions of complexed $\mathrm{Ni}^{\mathrm{II}}$ to $\mathrm{Ni}^{0}$ whereas, on the reverse sweep, up to three oxidation peaks occur in each case. The peaks that are absent in the cyclic voltammograms of the free ligands are located at $+0.47 \mathrm{~V}$ (ligand $\mathrm{H}_{2} \mathrm{~L} 1$ ) and $+0.66 \mathrm{~V}$ (ligand $\mathrm{H}_{2} \mathrm{~L} 2$ ). These peaks can be associated to the irreversible oxidation of $\mathrm{Ni}^{0}$ to $\mathrm{Ni}^{\mathrm{II}}$. The electrochemical responses of the $\mathrm{Ni}$ (II) compounds are essentially the same with minor shifts in the potential values (Table 3 ), and agree with those previously described for nickel complexes in the same solvent [46].

In addition, a linear dependence was observed between $i_{\mathrm{p}}$ and $v^{1 / 2}$ and $E_{\mathrm{p}}$ and $i_{\mathrm{p}}$ as the voltage scan rate $(v)$ was increased (i.e., at $100,200,300$, and $500 \mathrm{mV} \cdot \mathrm{s}^{-1}$ ), indicating a diffusion controlled electron exchange reaction. The plot of $i_{\mathrm{pa}}$ for the oxidation peak potential of $\mathrm{Ni}(\mathrm{II}) \mathrm{L} 1$ and that of $\mathrm{Ni}(\mathrm{II}) \mathrm{L} 2$, each as a function of the square root of the scan rate (not shown), gave a straight line parallel to the horizontal axis $\left(\log _{10} v\right)$ indicating a quasireversible electrode exchange reaction [42]. Furthermore, the ratio $i_{\mathrm{pc}} / i_{\mathrm{pa}}$ was independent of scan rate and equal to unity for scan rates varying from $100 \mathrm{mV} \cdot \mathrm{s}^{-1}$ to $1 \mathrm{~V} \cdot \mathrm{s}^{-1}$.

Finally, the cadmium(II) complexes also undergo reduction processes located at $-1.43 \mathrm{~V}$ for $\mathrm{Cd}$ (II)L1 (Fig. 2g) and $-1.50 \mathrm{~V}$ for Cd(II)L2 (Fig. 2h). These peak values correspond to the reduction of $\mathrm{Cd}^{\mathrm{II}}$ to $\mathrm{Cd}^{0}$. The reoxidations at $+0.45 \mathrm{~V}$ for $\mathrm{Cd}(\mathrm{II}) \mathrm{L} 1$ and $+0.52 \mathrm{~V}$ for $\mathrm{Cd}(\mathrm{II}) \mathrm{L} 2$ are due to the oxidation of $\mathrm{Cd}^{0}$ back to coordinated $\mathrm{Cd}^{\mathrm{II}}$.

When the scan rate changes, this last single reduction peak (at $-1.50 \mathrm{~V}$ ) sometimes is decomposed into two waves and the second peak is often more distinct than the first. These two successive reduction peaks are observed in the cyclic voltammogram of Cd(II)L2 at various scan rates $\left(100\right.$ to $\left.10 \mathrm{mV} \cdot \mathrm{s}^{-1}\right)$, but $\mathrm{Cd}(\mathrm{II}) \mathrm{L} 1$ gives only one peak in each case. A similar behavior has been observed for other symmetric Schiff bases [45, 47].

\subsection{Proposed Structures}

The proposed structures are given in Fig. 3. The cobalt(II), cadmium(II) and nickel(II) compounds exhibit the same structure. These species are binuclear complexes and the coor-

Fig. 3 The proposed structures for the complexes $\mathrm{R}=\mathrm{H}\left(\mathrm{H}_{2} \mathrm{~L} 1\right)$ or $\mathrm{OH}\left(\mathrm{H}_{2} \mathrm{~L} 2\right)$

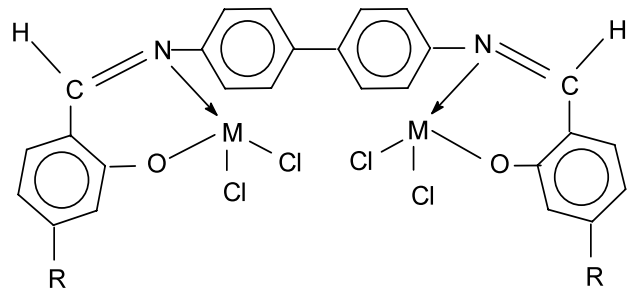

$M=\mathrm{Co}, \mathrm{Cd}$ or $\mathrm{Ni}$ (with $2 . \mathrm{H}_{2} \mathrm{O}$ in case of ligand $\mathrm{H}_{2} \mathrm{~L}$ ) 
dination of the metal ions is through nitrogen and oxygen atoms. The cobalt(II) and the cadmium(II) compounds present a distorted tetrahedral geometry while the nickel(II) complexes exhibit a typical square planar structure [48]. In addition, two water molecules are present in the case of the nickel(II) complex (ligand $\mathrm{H}_{2} \mathrm{~L} 1$ ) as indicated by infrared spectroscopy and thermal analysis.

\section{References}

1. Garnovskii, A.D., Nivorozhkin, A.L., Minkin, V.I.: Ligand environment and the structure of Schiff base adducts and tetracoordinated metal-chelates. Coord. Chem. Rev. 126, 1-69 (1993)

2. Cozzi, P.G.: Metal-Salen Schiff base complexes in catalysis: practical aspects. Chem. Soc. Rev. 33, 410421 (2004)

3. Ziessel, R.: Schiff-based bipyridine ligands. Unusual coordination features and mesomorphic behaviour. Coord. Chem. Rev. 216-217, 195-223 (2001)

4. Aubert, P.-H., Audebert, P., Roche, M., Capdevielle, P., Maumy, M.: Synthesis and electrochemical investigation of bis(Salen) complex precursors allowing the formation of a ladder-type polymer. Chem. Mater. 13, 2223-2230 (2001)

5. Frausto da Silva, J.J.R., Williams, R.J.P.: The Biological Chemistry of the Elements. Clarendon Press, Oxford (1991)

6. Kaim, W., Schwederski, B.: Bioinorganic Chemistry, Inorganic Elements in the Chemistry of Life. Wiley, New York (1996)

7. Coughlin, P.K., Lippard, S.J.: Copper(II) chemistry in hexaaza binucleating macrocycles: hydroxide and acetate derivatives. J. Am. Chem. Soc. 106, 2328-2336 (1984)

8. Zanello, P., Tamburini, S., Vigato, P.A., Mazzochim, G.A.: Syntheses, structure and electrochemical characterization of homo- and heterodinuclear copper complexes with compartmental ligands. Coord. Chem. Rev. 77, 165-273 (1987)

9. Vigato, P.A., Tamburini, S., Fenton, D.E.: The activation of small molecules by dinuclear complexes of copper and other metals. Coord. Chem. Rev. 106, 25-170 (1990)

10. Katsuki, T.: Catalytic asymmetric oxidations using optically active (Salen) manganese(III) complexes as catalysts. Coord. Chem. Rev. 140, 189-214 (1995)

11. Samsel, E.G., Srinivasan, K., Kochi, J.K.: Mechanism of the chromium-catalyzed epoxidation of olefins. Role of oxochromium(V) cations. J. Am. Chem. Soc. 107, 7606-7617 (1985)

12. Elmorsi, M.A., Gabor, M., Barendrecht, E.: Cathodic reduction of oxygen at new iron complexes. J. Appl. Electrochem. 21, 1005-1012 (1991)

13. Bermejo, M.R., Castineiras, A., Garcia-Monteagudo, J.C., Rey, M., Sousa, A., Watkinson, M., McAuliffe, C.A., Pritchard, R.G., Beddose, R.L.: Electronic and steric effects in manganese Schiff-base complexes as models for the water oxidation complex phitosystem. II. The isolation of manganese-(II) and -(III) complexes of 3- and 3,5-substituted N,N'-bis(salicylidene)ethane-1,2-diamine $\left(\mathrm{H}_{2}\right.$ Salen) ligands. J. Chem. Soc., Dalton Trans. 2935-2944 (1996)

14. Watkinson, M., Fonda, M., Bermejo, M.R., Sousa, A., McAuliffe, C.A., Pritchard, R.G., Jaiboon, N., Aurangzeb, N., Naeem, M.: Further attempts to rationalise the co-ordination chemistry of manganese with Schiff base ligands and supplementary carboxylate donors. J. Chem. Soc., Dalton Trans. 31-42 (1999)

15. Briley, N.A., Rodriguez de Barbarin, C.O., Fenton, D.E., Hellier, P.C., Hempstead, M., Danezato, P.D., Leeson, P.B.: Attempted functionalization of a mononuclear barium complex of a 24-membered bibracchial tetraimine Schiff-base macrocycle derived from tris(2-aminoethyl)amine using salicylaldehyde. J. Chem. Soc., Dalton Trans. 765-770 (1995)

16. Ngwenya, M.P., Chen, D., Martell, A.E., Reibenspies, J.: Oxygenation of a copper(I) complex of a binucleating macrocyclic Schiff base ligand derived from 1,4,7-triazaheptane and furan-2,5dicarboxaldehyde. J. Inorg. Chem. 30, 2732-2736 (1991)

17. Fenton, D.E.: Tetraimine Schiff base macrocycles derived from heterocyclic dicarbonyles. Pure Appl. Chem. 58, 1437-1444 (1986)

18. Jacobson, K.B., Turner, J.E.: The interaction of cadmium and certain other metal ions with proteins and nucleic acids. Toxicology 16, 1-37 (1980)

19. Hidalgo, H.A., Koppa, V., Bryan, E.S.: Effects of cadmium on RNA—polymerase and protein synthesis in rat liver. FEBS Lett. 64, 159-162 (1976)

20. Dakternieks, D.: Zinc and cadmium. Coord. Chem. Rev. 98, 279-294 (1990) 
21. Cai, Y.P., Su, C.Y., Xu, A.W., Kang, B.S., Tong, Y.X., Liu, H.Q., Jie, S.: Syntheses and characterization of copper(II) complexes of bis(acetylacetone)trimethylenediimine. Polyhedron 20, 657-662 (2001)

22. Reddy, K.H., Reddy, M.R., Raju, K.M.: Syntheses, characterization, electrochemistry and axial ligation properties of macrocyclic divalent metal complexes of acetylacetone buckled with different diamines. Polyhedron 16, 2673-2679 (1997)

23. Boucher, L.J., Herrington, D.R.: Manganese Schiff base complexes. III. Circular dichroism of tetradentate chelates of manganese III. Inorg. Chem. 13, 1105-1108 (1974)

24. Matsushita, T., Kono, H., Shono, T.: The preparation and characterization of dichloromanganese(IV) Schiff base complexes. Bull. Chem. Soc. Jpn. 54, 2646-2651 (1981)

25. Khandar, A.A., Hosseini-Yazdi, S.A., Zarei, S.A.: Syntheses, characterization and X-ray crystal structures of copper(II) and nickel(II) complexes with potentially hexadentate Schiff-base ligands. Inorg. Chim. Acta 358, 3211-3217 (2005)

26. Kessissoglou, D.P., Kirk, M.L., Lah, M.S., Li, X., Raptopoulou, C., Hatfield, W.E., Pecoraro, V.L.: Structural and magnetic characterization of trinuclear mixed-valence manganese acetates. Inorg. Chem. 31, 5424-5432 (1992)

27. Saydam, S., Alakn, C.: Synthesis and characterization of a new thiazole Schiff base 5-bromo-2hydroxybenzylidene-2-aminobenzothiazole and its complexes with $\mathrm{Co}(\mathrm{II}), \mathrm{Cu}(\mathrm{II})$ and Ni(II). Polish J. Chem. 75, 29-33 (2001)

28. Gili, P., Martin-Reyes, M.G., Martin-Zarza, P., Machado, I.L.F., Guedes da Silva, M.F.C., Lemos, M.A.D.A., Pombiero, A.J.L.: Syntheses, spectroscopic, magnetic and electrochemical properties of $\mathrm{Cu}(\mathrm{II})$ and $\mathrm{Fe}(\mathrm{III})$ complexes with the new ligand $\mathrm{N}, \mathrm{N}^{\prime}-\left[1,1^{\prime}\right.$-dithiobis(phenyl)]bis $\left(5^{\prime}\right.$ methoxysalicylaldimine). Inorg. Chim. Acta 244, 25-36 (1996)

29. Gili, P., Martin-Reyes, M.G., Martin-Zarza, P., Machado, I.L.F., Guedes da Silva, M.F.C., Tong, Y.Y., Pombiero, A.J.L.: Complexes of $\mathrm{Mn}(\mathrm{II})$ and $\mathrm{Mn}$ (III) with the Schiff base N-[2-(3ethylindole)]pyridoxaldimine. Electrochemical study of these and related $\mathrm{Ni}(\mathrm{II})$ and $\mathrm{Cu}(\mathrm{II})$ complexes. Inorg. Chim. Acta 255, 279-288 (1997)

30. Vogt, A., Wolowiec, S., Prasad, R.L., Gupta, A., Sharzewski, J.: Syntheses and characterization of nickel(II), copper(II), manganese(III) and iron(III) complexes with new chiral Salen-type ligand $\mathrm{N}, \mathrm{N}^{\prime}$-bis(3,5-di-tert-butylsalicylidene)-(1R,3S)-1,3-diamine-1,2,2-trimethylcyclopentane. Polyhedron 17, 1231-1240 (1998)

31. Cimerman, Z., Galic, N., Bosner, B.: The Schiff bases of salicylaldehyde and aminopyridines as highly sensitive analytical reagents. Anal. Chim. Acta 343, 145-153 (1997)

32. Lalia-Kantouri, M., Hartophylles, M., Jannakoudakis, P.D., Voutsas, G.P.: Spectral and electrochemical features of some substituted bis(2-hydroxyaryloximato) $\mathrm{Co}(\mathrm{II}), \mathrm{Ni}(\mathrm{II}), \mathrm{Pd}(\mathrm{II})$ and $\mathrm{Cu}(\mathrm{II})$ chelates. Crystal and molecular structure of trans-bis(propanone,1-[2-hydroxyphenyl]-oximato)Ni(II). Z. Anorg. Allg. Chem. 621, 645-653 (1995)

33. Hassaan, A.M., Khalifa, M.A.: Metal chelates of some transition and non-transition metal ions with Schiff base derived from isatin with $o$-phenylenediamine. Monatsh. Chem. 124, 803-808 (1993)

34. Ali, M.A., Mirza, A.H., Butcher, R.J.: Synthesis and characterization of copper(II) complexes of the methylpyruvate Schiff base of S-methyldithiocarbazate (Hmpsme) and the X-crystal structures of Hmpsme and [Cu(mpsme)Cl]. Polyhedron 20, 1037-1043 (2001)

35. Felicio, R.C., Da Silva, G.A., Ceridorio, L.F., Dockal, E.R.: Tetradentate Schiff base copper(II) complexes. Synth. React. Inorg. Met.-Org. Chem. 29, 171-192 (1999)

36. Abu-El-Wafa, S.M., Issa, R.M., McAuliffe, C.A.: Unusual Cu(III) Schiff's base complexes. Inorg. Chim. Acta 99, 103-106 (1985)

37. Lechat, S., Khan, M.A., Bouet, G.M., Vierling, F.: Spectrophotometric study of cobalt(II) chloride complexes in ethanol and propan-2-ol. Inorg. Chim. Acta 211, 33-36 (1993)

38. Lever, A.B.P.: Inorganic Electronic Spectroscopy, 1st edn. Elsevier, Amsterdam (1968)

39. Abd-Elzaher, M.M.: Spectroscopic characterization of some tetradentate Schiff bases and their complexes with nickel, copper and zinc. J. Chin. Chem. Soc. 48, 153-160 (2001)

40. Gulloti, M., Casella, L., Pasini, A., Ugo, R.: Optically active complexes of Schiff base. Part 3. Complexes of iron(III) with quadridentate Schiff-bases derived from salicylaldehyde. J. Chem. Soc., Dalton Trans. 339-345 (1977)

41. Anthonysamy, A., Balasubramanian, S.: Synthesis, spectral, thermal and electrochemical studies of nickel(II) complexes with $\mathrm{N}_{2} \mathrm{O}_{2}$ ligands. Inorg. Chem. Commun. 8, 908-911 (2005)

42. Kaabi, I., Douadi, T., Haffar, D., Chafaa, S., Allain, M., Khan, M.A., Bouet, G.M.: Crystal structure of a new pentadentate symmetrical: di[4-(phenylimino)penta-2-one] ether. Structural and electrochemical studies of its $\mathrm{Co}^{\mathrm{II}}, \mathrm{Ni}^{\mathrm{II}}, \mathrm{Cu}^{\mathrm{II}}$ and $\mathrm{Cd}^{\mathrm{II}}$ complexes. Transit. Met. Chem. 32, 666-673 (2007)

43. Cavalheiro, E.T.G., Lemos, F.C.D., Zukerman Schpector, J., Dockal, E.R.: The thermal behaviour of nickel, copper and zinc complexes with the Schiff bases cis- and trans-N,N'-bis(salicylidene)-1,2cyclohexadiamine (Salen). Thermochim. Acta 370, 129-133 (2001) 
44. Chavan, M.Y., Meade, T.J., Busch, D.H., Kuwana, T.: Structural dependence of an electron-transfer process: nature of the product of one-electron oxidation of the lacunar cyclidene complexes of nickel(II) and cobalt(II). Inorg. Chem. 25, 314-321 (1986)

45. Beloglazkina, E.K., Majouga, A.G., Romashkina, R.B., Moiseeva, A.A., Zyk, N.V.: The preparation, crystal structure and electrochemistry of $\left(5 Z, 5^{\prime} Z\right)-2,2^{\prime}$-(alkane- $\alpha, \omega$-diylsulfanyldiyl)bis (5-(3pyridylmethylene)-3,5-dihydro-4-imidazol-4-ones) and their complexes with cobalt(II) chloride. Polyhedron 26, 797-802 (2007)

46. Lintvedt, R.L., Ranger, G., Kramer, L.S.: Cyclic voltammetric study of a series of related mono- and binuclear nickel complexes of beta di- and triketonates and their diamine Schiff bases. Inorg. Chem. 25, 2635-2637 (1986)

47. Ourari, A., Ouari, K., Moumeni, W., Sibous, L., Bouet, G.M., Khan, M.A.: Unsymmetrical tetradentate Schiff base complexes derived from 2,3-diaminophenol and salicylaldehyde or 5-bromosalicylaldehyde. Transit. Met. Chem. 31, 169-175 (2006)

48. Lever, A.B.P.: Inorganic Electronic Spectroscopy, 2nd edn. Elsevier, Amsterdam (1984) 